\title{
Resilience of Pontian Farmers in the Face of the Impact Changes of Rapid Development in Iskandar Malaysia
}

\author{
Joharudin Samion \\ Greenovation Research Group, Faculty of Built Environment and Surveying, Universiti Teknologi Malaysia, 81310 UTM Johor Bahru, Malaysia. \\ Ismail Said and Tun M Irfan Mohd Suria Affandi \\ Greenovation Research Group, Faculty of Built Environment and Surveying, Universiti Teknologi Malaysia, 81310 UTM Johor Bahru, Malaysia \\ Lee Yoke Lai \\ Department of Landscape Architecture, Faculty of Built Environment and Surveying, Universiti Teknologi Malaysia, 81310 UTM Johor Bahru, \\ Malaysia.
}

\begin{abstract}
The issues of community resilience arise from the need to develop an understanding of how people would respond to internal and external disturbances. In-depth discussion towards the impact of a city to a neighbouring district has little been discussed. The District of Pontian is located west of Iskandar Malaysia. It has received an unprecedented level of infrastructural development to boost the economy of Iskandar Malaysia. This study examines the land use pattern change of Pontian District impacted by Iskandar Malaysia. Additionally, the study aims to assess the social, economic and environmental capital and the factors that contribute to the adaptabilities and resilience of farmer communities in Pontian. Build-up area for each period using Google earth satellite imagery from the year 2005 to 2015, was classified to analyze the change of build-up area. Markov Chains technique is applied to predict changes of land use. Next, survey questionnaires were utilized to measure the levels of community resilience. Subsequently, an interview was employed to identify the factors that contribute to the stresses. The results indicate that rapid development of Iskandar Malaysia gave an impact to agricultural land and changed the land use pattern of Pontian. The findings revealed the perspective of individuals, community, and system resilience capacity to survive. It was found that farmers were able to adapt to various stresses. The result indicates that individuals and communities can be adaptive, absorptive, and transformative. The findings can assist in formulation of strategies for communities to be better prepared for the current and future impact of the triple threat of urbanization, globalization and climate change.
\end{abstract}

\section{Article History}

Received : 30 July 2020

Received in revised form: 01 January 2021

Accepted: 18 February 2021

Published Online: 30 April 2021

\section{Keywords:}

Community resilience, Iskandar Malaysia, Farmer community

\section{Corresponding Author Contact:}

b-ismail@utm.my

DOI: $10.11113 /$ ijbes.v8.n2.676

\section{Introduction}

After thirteen years of its existence, Iskandar Malaysia has grown into a region now recognized as a global brand. It started under the 9th Malaysian Plan when southern Johor was identified as one of the national development corridor. Khazanah was given the mandate in 2005 to proposed and came out with a plan to develop a new economic zone in the state of Johor, which was then known 
as South Johor Economic Region (SJER). The new region will be developed to become a sustainable metropolis with a vision to be known at international level. Since 2006, when Iskandar Malaysia was adopted as one of the economic corridors in Malaysia, Iskandar Malaysia has brought in more focused in the area of economic and infrastructure investments to the optimum level. The established of these new urban conurbation which strategically located at the southernmost tip of Peninsular Malaysia has progressed rapidly and managed to draw in a large number of domestic and international investment. Five local authorities fall under the jurisdiction of the three districts, namely Johor Bahru, Kulai and Pontian are included in Iskandar Malaysia. The five local authorities are Johor Bahru City Council, Iskandar Puteri City Council, Pasir Gudang Municipal Council, Kulai Municipal Council and Pontian District Council. Since Iskandar Malaysia was recognised as the Iskandar Development Region in 2006, it has contributed significantly to the economy of the state of Johor. At the state level, it contributes nearly three-quarters of the state gross domestic product and about 47 per cent of the employment of Johor (Authority, Comprehensive Development Plan ii, 2014).

Seemingly without surprising, urbanization impact on land-use change has now manifested in Pontian district. Moreover, the issue of land use alterations in Pontian for the last thirteen years threatened the communities. Pontian district was chosen because of the acceleration of economic development and infrastructure expansion commencing from Iskandar Malaysia development (refer to Table 1). Certainly, the prominent economic sectors are industry and trade based activities concentrated in Pontian region (Authority, Comprehensive Development Plan i, 2006) where most land banks in this area are agriculture land and mangrove forest. As such, the large tract of its land is purchased by developers and turned into industrial, residential and commercial uses. In short, most of the developments in this district fail to confront Pontian Local Plan (2002-2015) (refer to Figure 1 and Figure 2), and the trend of no confirmation is accelerating to this date. Besides, urbanization threats had to change the social, economic and environmental structure of Pontian communities where most of the communities in the nearby area are farmers and fishermen. Thus, the understanding of the resilience issues and community adaptation is vital. Accordingly, the purpose of this research is to evaluate land use pattern change in Pontian district and its relationship to social, economic and environmental capital applied to community resilience. This research will become a guide for sustainable land use planning and predict the future development direction of Pontian district, which is to reduce the chronic stress imposed on the community.

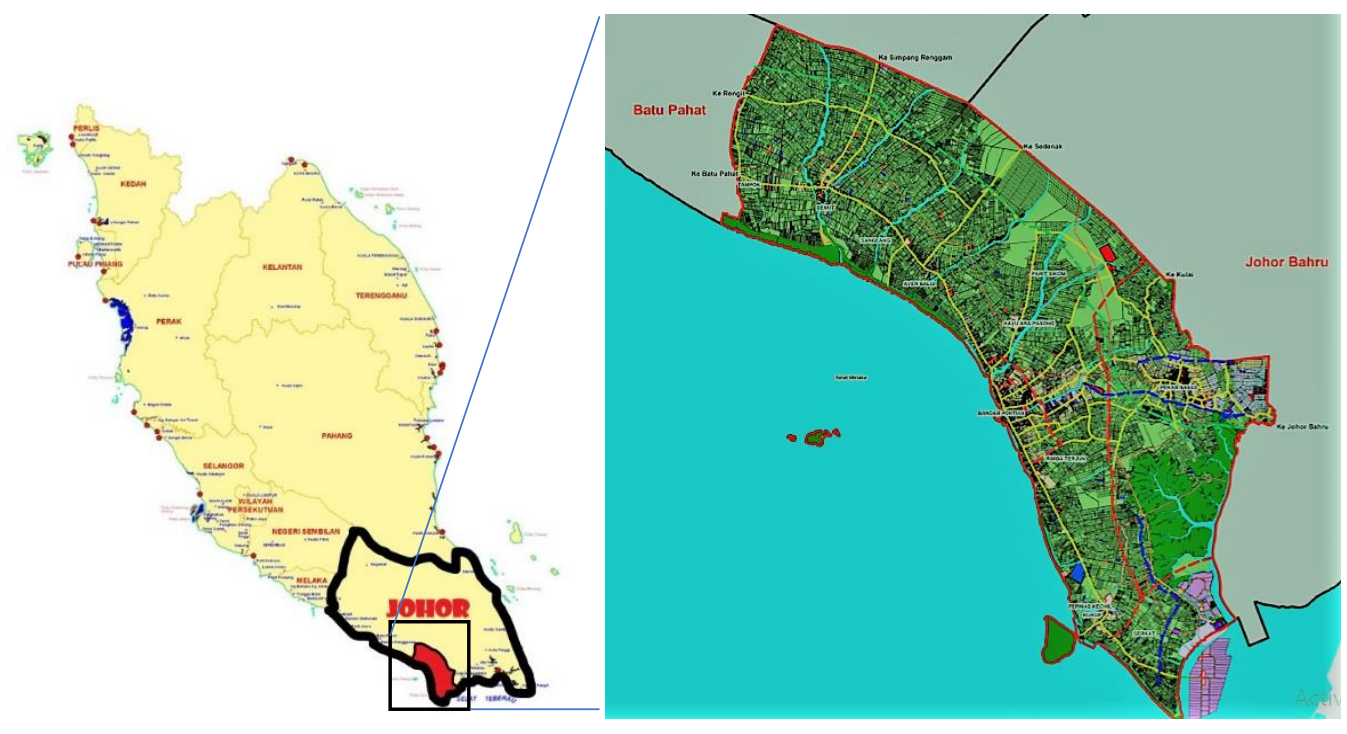

Figure 1 Map of Pontian Source: Pontian District Council Local Plan 2030

Table 1 Land Use 2010 and 2015

\begin{tabular}{l|c|c|c|c|c}
\hline \multicolumn{1}{c|}{ LAND USE } & $\mathbf{2 0 1 0}$ (HEK) & $\mathbf{\%}$ & $\begin{array}{c}\text { COMMITED } \\
\text { DEVELOPMENT } \\
\text { (HEK) }\end{array}$ & 2015 (HEK) & \% \\
\hline $\begin{array}{l}\text { Landuse (housing, business, } \\
\text { industrial, institution \& } \\
\text { public infrastructure) }\end{array}$ & $2,552.60$ & 2.99 & $6,252.82$ & $8,805.42$ \\
\hline Infrastructure \& Utility & $3,958.55$ & 4.34 & 18.93 & $3,977.48$ & 4.60 \\
\hline Forest \& RAMSAR & $12,182.71$ & 14.26 & - & $12,182.71$ & 13.29 \\
\hline Agriculture & $72,993.04$ & 78.11 & - & $66,721.28$ & 72.77 \\
\hline TOTAL & $\mathbf{9 1 , 6 8 6 . 9 0}$ & $\mathbf{1 0 0 . 0 0}$ & $\mathbf{6 , 2 7 1 . 7 5}$ & $\mathbf{9 1 , 6 8 6 . 9 0}$ & $\mathbf{1 0 0 . 0 0}$ \\
\hline
\end{tabular}




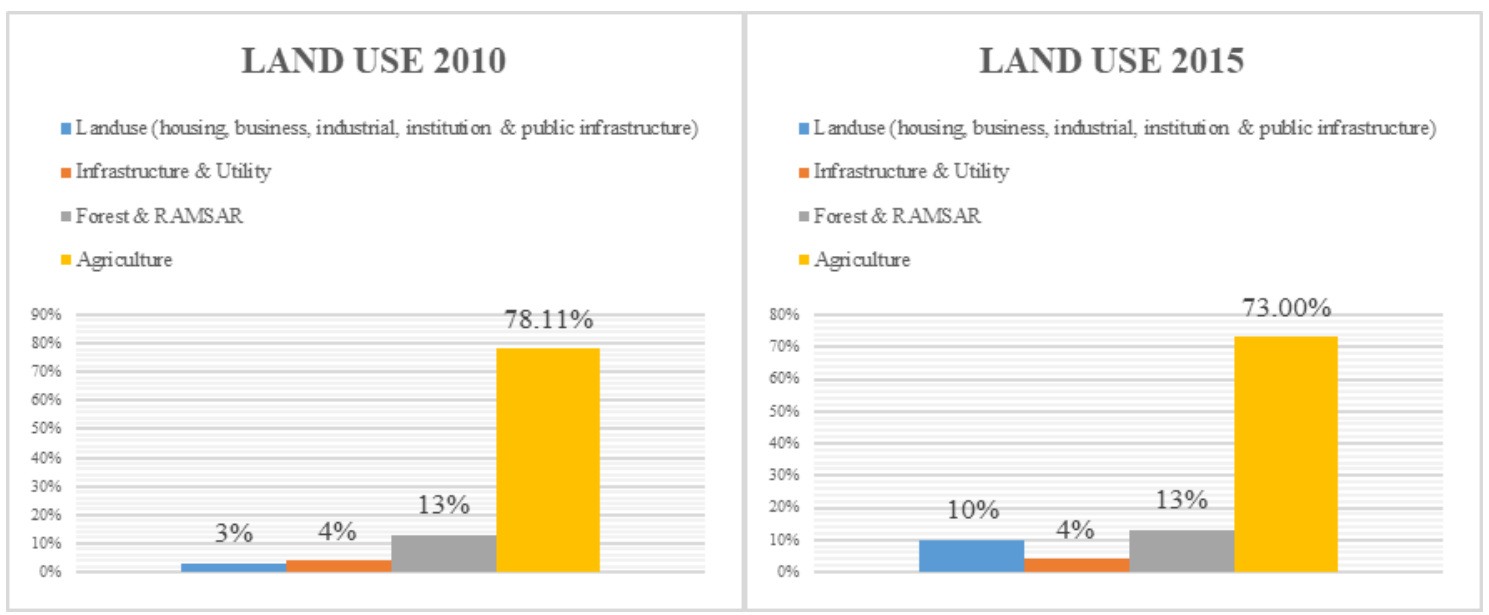

Figure 2 Comparison of Land Use 2010 and 2015

Source: Pontian District Council Local Plan 2002-2015 (revised 2010)

\section{Theoretical Background}

In general, research on community resilience is still new. The issues of community resilience arise from the need to develop an understanding of how people would respond to internal and external disturbances. Although much study has been done on environmental and social resilience, the study on community resilience has received little attention, and little work exists on the possible interlinkages (Folke, 2006). However, lately, community resilience begins to emerge definitions that are more measured and more practical and realistic. Resilience has been a popular term parallel with sustainability, particularly in the field of urban planning. Indeed, a conception of resilience in urban planning and urban design perspective borrowed from how ecological system studies can cope with the uncertainties triggered by the external factors and stresses (David \& Welsh, 2004).

Most resilience studies focus on how each city can withstand or adapt from any potential threat to society, economy, and environment. There are few factors either it internal or external forces found in various literatures can influence the community resilience, such as threats, shocks, perturbation, disasters, hazards, disruption, and disturbances ( (Folke, 2006); (Forbes, et al., 2009); (Magis, 2010)). The elucidation of resilience, mainly on communities, responds and reacts towards acute shocks. Acute shocks are referring to an unexpected natural catastrophe (e.g., hurricane, earthquake or volcanic eruption) and very few studies discussed in-depth on rapid development impact against the neighboring district of a city which potentially imposed chronic stresses. Chronic stresses are referring to stresses that imposed to the community due to the physical development. The massive development may create homelessness and unaffordable housing, poverty and inequity, crime and safety, education, healthcare, high unemployment, economic diversity and vibrancy, land use and availability, transportation network, ageing infrastructure, rising sea level and coastal erosion, pollution and environmental degradation (Gordon, 2014). Hence it is essential to investigate how communities, especially farmers in Pontian to adapt and prolonged living to the economy, social and physical development alterations. As development escalates with demand, the more plantation lands are traded with infrastructure, and housing to accommodate the excessive growth in the human population and industrial development. In this study, the community resilience will be measured base on the understanding of the same value interlink concept brought by (Wilson G., 2012) and the adaptation from the chronic stress factors by (Gordon, 2014). Interrelation among three significant components of community development, according to (Wilson G., 2010) has the potential to create different classification of resilience or vulnerability (refer to Figure 3).

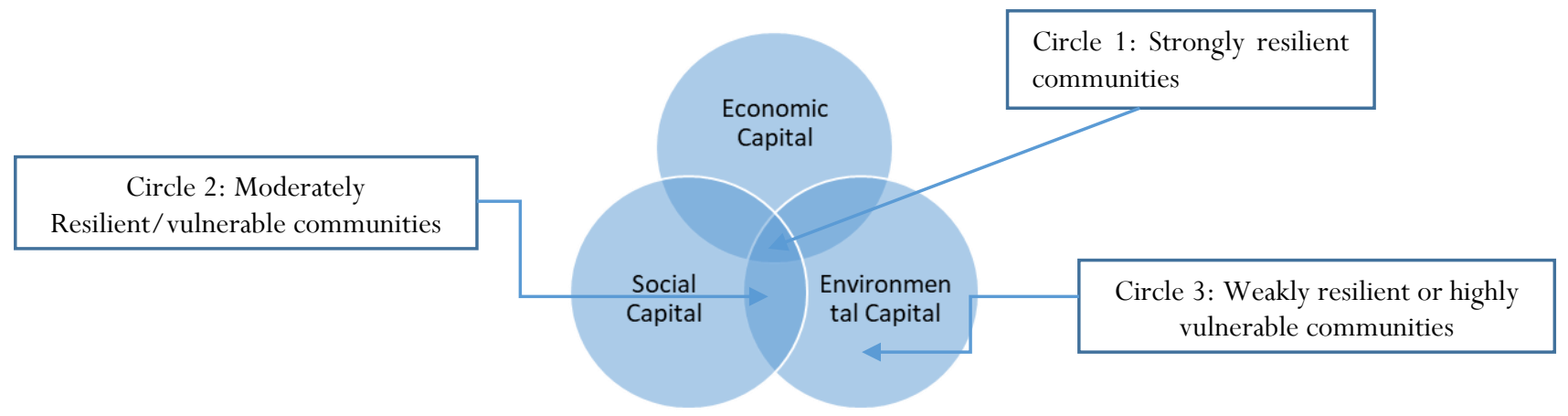

Figure 3 Community resilient and vulnerability measure using economic social and environmental capitals. Source: (Wilson G. , 2010) 
(Wilson G., 2010) designates the centre core (or core area), where there is balanced interception of economy, social, and environmental capitals of the communities. As for communities with any two capitals which are well developed are considered as moderately resilient or vulnerable communities, while for communities with only one developed capital (or none) categorized as weakly resilient or highly vulnerable communities. In short, community resilience would be achieved through efforts to create and maintain the balance needs in economic, social, and environmental capitals. The economic capital of a community generally stresses the importance of maintaining the community's financial stability through a provision of jobs with a more stable income, and diversification of economic activities. In contrast, social capitals highlight the need for self-development among the members of the communities through training and education, for example, by acquiring appropriate skills and knowledge for the current situation and needs. The community social capital of a community also encourages the maintenance of the relationship among the members of the community through participation in decision-making processes, leadership, and organizational structures as well as empowerment of minority (or female) group. Finally, environmental capital gives more emphasis on issues of pollutions and poor management of natural resources. These factors, in turn, are expected to improve the economic wellbeing of the people within the community. The understanding of these indicators will become a guide to formulate the questionnaire to suit with the farmer community that will be measured.

\section{Method}

There are two steps of analysis. The first step of this research is to investigate the land use pattern change of Pontian from the year 2005 to 2015 and the second step is to evaluate how the land uses pattern impact farmer communities, economically, socially and environmentally.

\subsection{Step 1: Analyzing Land Use Pattern Change And Projection}

Geographical information system (GIS) and remote sensing were used to investigate the land use pattern change in Pontian district. By assessing the land-use change's pattern in Pontian district, it provided the opportunity to evaluate the fast-growing urbanization process impacted by Iskandar Malaysia. The integration of GIS and remote sensing considered as powerful tool for land use and land cover (LULC) mapping of Iskandar Malaysia and Pontian (Jaiswal, Kumar, \& Mukherjee, 1999); (Yagoub \& Giridhar, 2006); (Misra, Ankita, R, \& Vethamony, 2015); (Mengistu, Daniel, \& Salami, 2008). Combined with IDRISI software, it can be used to expand the opportunities and predict the future land use of Pontian district. Data on land-use change in Pontian district measured in five phases, namely, data acquisition, image pre-processing, image classification, change detection, and projection of land use (Figure 4).
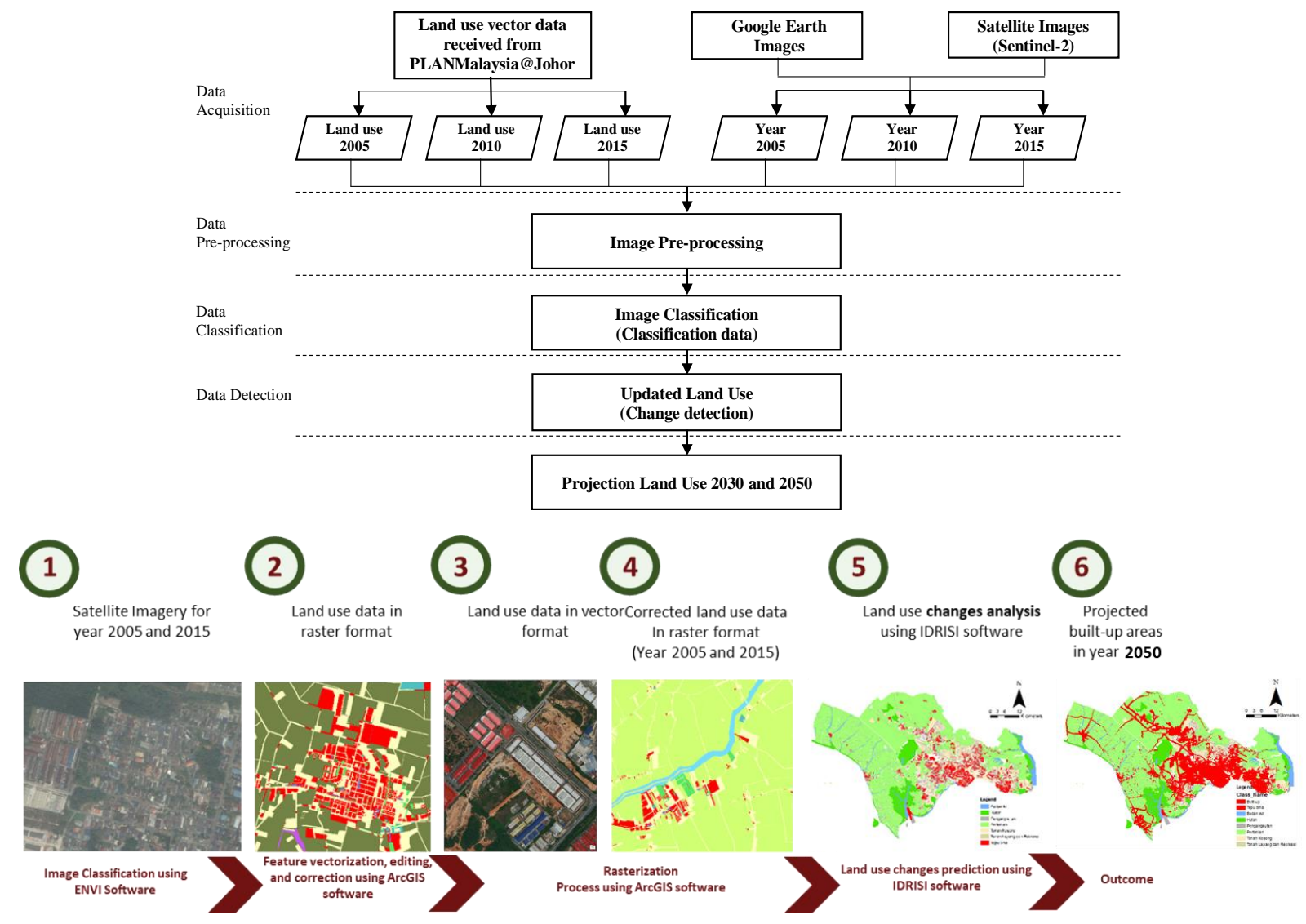

Figure 4 Flow chart of land use data processing and analysis in Pontian district 
As shown in Figure 4, the data sourced was from (1) vector data received from PLANMalaysia@Johor, (2) satellite images from Google Earth Images, and (3) sentinel-2 satellite images as raster data. The three different datasets were gathered from periods of 2005, 2010 and 2015 for both vector and raster images. Table 2 displayed datasets.

Table 2 Description of land use datasets of Pontian district

\begin{tabular}{l|l|l}
\hline \multicolumn{1}{c|}{ Data } & \multicolumn{1}{c}{ Description } & \multicolumn{1}{c}{ Sources } \\
\hline $\begin{array}{l}\text { Vector data: } \\
\text { i. Land use data } \\
\text { ii. The boundary of Johor district and IRDA }\end{array}$ & $\begin{array}{l}\text { Data received in shapefile format with } \\
\text { RSO Projected Coordinate System. }\end{array}$ & PLANMalaysia@Johor. \\
\hline $\begin{array}{l}\text { Raster data: } \\
\text { i. Satellite images }\end{array}$ & $\begin{array}{l}\text { Three (3) different satellite images for the } \\
\text { years 2005, 2010, and 2015. The original } \\
\text { data of google earth was in WGS84 } \\
\text { projection. Then the data were converted } \\
\text { to RSO Projection Coordinate System. }\end{array}$ & $\begin{array}{l}\text { Google Earth Images and Sentinel-2 } \\
\text { satellite images. }\end{array}$ \\
\hline
\end{tabular}

Generally, one of the main objectives of satellite remote sensing is to interpret the object and classify features based on reflectance pixel. Different types of objects on the earth covering Iskandar Malaysia and Pontian district have different spectral reflectance and remittance properties. The purpose of using both of the data format, vector, and raster, is to ensure the updates and completeness of the data (Rizk, Ibrahim, Mosbeh, \& Rashed, 2015). It is essential to scrutinize the quality of the data provided by PLANMalaysia@Johor. By given raw remotely sensed imageries, a set of different land cover can be categorized by applying Sentinal-2A images being classified by using ENVI software. This image was chosen due to its excellent characteristics. For instance, consists of 13-bands in the visible, near-infrared, and short-wave infrared, and also provides 10/20 meter of spatial resolution. The output from this process is classified data based on different land-use types in raster format. This result was then used with Google Earth imageries to validate and update the land use data of Iskandar Malaysia, including Pontian district that received from PLANMalaysia@Johor. Change detection from different landuse types and years that is 2005, 2010, and 2015. This process was done by using IDRISI software, specifically Land Change Modeller (LCM) application. LCM is an innovative land planning and decision support system that is fully integrated into the TerrSet software. The complexities of change analysis can be simplified by applying an automated and easy workflow of LCM system. LCM provides efficient analysis of land cover change, empirically model relationships to explanatory variables and can simulate projected land change in Iskandar Malaysia and Pontian district. The process of land use projection can be carried out by applying Markov Chains technique. In general, Markov Chains is a stochastic technique that widely used in identifying the change from one state to another by giving a transition probability matrix (Glenn-Lewin et al., 1992; Hu and Lo, 2007; Cabral and Zamyatin, 2009). The changes in land use patterns between different years would produce a probability transition matrix and further used to predict land use at specified dates.
The mathematical equation of the transition probability, as stated below:

$$
\begin{aligned}
& \sum_{i=1}^{m} P_{i j}=1 i=1,2 \ldots \ldots \ldots m \\
& P=\left(P_{i j}\right)=\begin{array}{ccc}
P 11 & P 12 \ldots & P 1 m \\
P 21 & P 12 & P 2 m \\
P m 1 & P n 2 & P m m
\end{array}
\end{aligned}
$$

where: $P_{i j}=$ the probability of transition from one land use to another, $m=$ the type of land use of the area studied, $P_{i j}$ values are within the range $0-1$.

\subsection{Step 2: To evaluate the impact of land-use change on Farmers in Pontian}

There are two methods used: questionnaires and interview. Questionnaires will be used to measure farmer's resilience level, whereas interview will be used to identify the factors that might cause the chronic stresses to the farmer community. A total of 30 questions will be used to measure resiliency of farmers in Pontian, addressing economic, social and environmental capitals as an indicator. The question will focus on indicator that helps to identify the critical resilience issues in the context of Pontian farmers. The data analysis section, involving the quantification of resilience for farmer community based on a ranking score from 0 which will be shown as the indication of high vulnerability, to 10 , which will indicate strong resilience. The same approach has also been used by (Gahin, Veleva, \& Hart, 2003), (Western, Stimson, Baum, \& Van Gellecum, 2005), (Thomalla \& Klocker Larsen, 2010), and (Nurul Islam, Yew, Abdullah, \& Viswanathan, 2011). The specific average scores which then be calculated for each of the three capitals in farmer community to establish an overall average for the economic, social and environmental capital (Refer Figure 5). 
STRONG COMMUNITY RESILIENCE

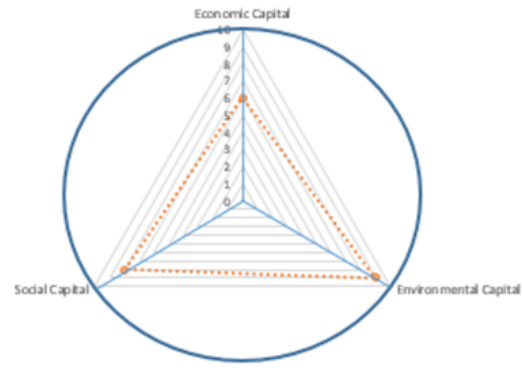

Community A

Resilience/Vulnerability score $=7.7$
WEAK COMMUNITY RESILIENCE

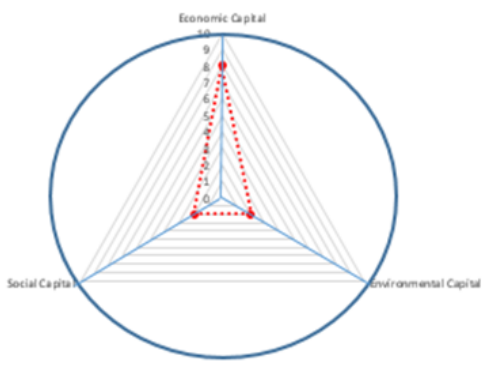

Community B

Resilience/Vulnerability score $=4.0$

Figure 5 Hypothetical example of two case study communities with high and low resilience scores based on the quantification of social, economic and environmental capital. Source: (LEDDRA, 2011)

Primary data were based on the standardized questionnaire collected from 5 sub-districts in Pontian within Iskandar Malaysia. Primary data were gathered using quantitative (via questionnaire guided survey), and SPSS 24 software will be used to analyze the result. The survey questionnaire was formulated based on the list of indicators proposed in Table 3 and divided into three capitals. There are 30 questions in total; economic capital with nine indicators, social capital with 13 indicators and environmental capital with eight indicators.

Table 3 List of specific resilient community indicator

\begin{tabular}{|c|c|}
\hline $\begin{array}{l}\text { Community's } \\
\text { Resilient Issues }\end{array}$ & Proposed Specific Questionnaire \\
\hline 1.Economic Capital & $\begin{array}{l}\text { a. Do your income has increased compared to the last } 10 \text { years. } \\
\text { b. Do you have a more stable income now as farmers? } \\
\text { c. Do you and your family depend on money from relatives living and working outside the community? } \\
\text { d. There is no need for you and your family household to develop multiple sources of income. } \\
\text { e. The locally produced goods product only sold locally. } \\
\text { f. The government give enough financial aids, funds, subsidize and welfare of the community. } \\
\text { g. You have been involved in making decisions within the community on matters of economic activities. } \\
\text { h. There are opportunities for new business and potential economic development in your communities. } \\
\text { i. Do you and the local community can get additional income due to the development of Iskandar Malaysia. }\end{array}$ \\
\hline 2.Social Capital & $\begin{array}{l}\text { a. Do you feel happy with the current situation compared to the last } 10 \text { years? } \\
\text { b. Do you feel proud to be part of the community? } \\
\text { c. Do you intend to live and continue to stay with the community? } \\
\text { d. Do you know/trust your neighbor? } \\
\text { e. Do you got involved in new developing opportunities/projects in the community? } \\
\text { f. Do you always agreed and obey the decision made by the local leaders and committee members in the } \\
\text { g. Dommunity? } \\
\text { h. Several agencies and relevant authorities effectively performing their tasks. } \\
\text { i. Various types of new skill training and knowledge available in the community. } \\
\text { j. The local knowledge and skills passed on from the older to the younger generation. } \\
\text { k. New knowledge and skills shared from younger to older generations. } \\
\text { l. Can you adapt to the changes and the development of Iskandar Malaysia? } \\
\text { m. Social problem reduced due to the new development of Iskandar Malaysia. }\end{array}$ \\
\hline $\begin{array}{l}\text { 3.Environmental } \\
\text { Capital }\end{array}$ & $\begin{array}{l}\text { a. Natural resources still in good condition. } \\
\text { b. Natural resources were improved and manage well by relevant government agencies. } \\
\text { c. The necessary infrastructure such as electricity, access to clean water, the road was improved. } \\
\text { d. A natural disaster such as flood was reduced in your community. } \\
\text { e. The cultural issue such as "pollution" is not an issue in the community. } \\
\text { f. Everyone involved in planning and the use of natural resources in the community. } \\
\text { g. New policy and laws well implemented by relevant government authorities really help the local } \\
\text { community. }\end{array}$ \\
\hline
\end{tabular}


h. The government, through relevant agencies, helps solve the issue raised by the local community concerning environmental issues.

An adaptation from: [ (Kamarudin, Ngah, Razak, Ibrahim, \& Harun, 2014); ( (Ekins, Simon, Deutsch, Folke, \& De Groot, 2003); (Lebel, et al., 2006); (Smit \& Wandel, 2006); (Parnwell, 2007); (Chaskin, 2008); (Cutter, et al., 2008); (Ostrom, 2009); (Magis, 2010); (Oudenhoven, Mijatovic, \& Eyzaguirre, 2010) in (Wilson G. , 2012, pp. 22-29)]

The interview was formulated based on the three questions to identify what are the factors that worry them economically, socially and environmentally. Interview will be used to identify the factors that might cause the chronic stresses to the farmer community. Chronic stresses are referring to stresses that imposed to the community due to the development. That may create homelessness and unaffordable housing, poverty and inequity, crime and safety, education, healthcare, high unemployment, economic diversity and vibrancy, land use and availability, transportation network, ageing infrastructure, rising sea level and coastal erosion, pollution and environmental degradation. (Gordon, 2014). The data were gathered using qualitative, and NVivo 12 will be used to analyze the result.

\section{Result and Findings}

\subsection{Land-use Change Detection Analysis and Projection}

The outcome of the transformation pattern land use in Pontian for the last 15 years and the investigation of land-use change pattern in Pontian district. Google Earth satellite imagery for the years 2005, 2010 and 2015 was used to generate graphs and maps of the land-use change, including gains and losses, net change, persistence and specific transitions (refer Figure 6.). Each period was classified by using ENVI and ArcGIS software. The result then combined with IDRISI software. MARKOV chain technique is then used to predict the land use built-up area by 2030 and 2050 (refer to Figure 7).

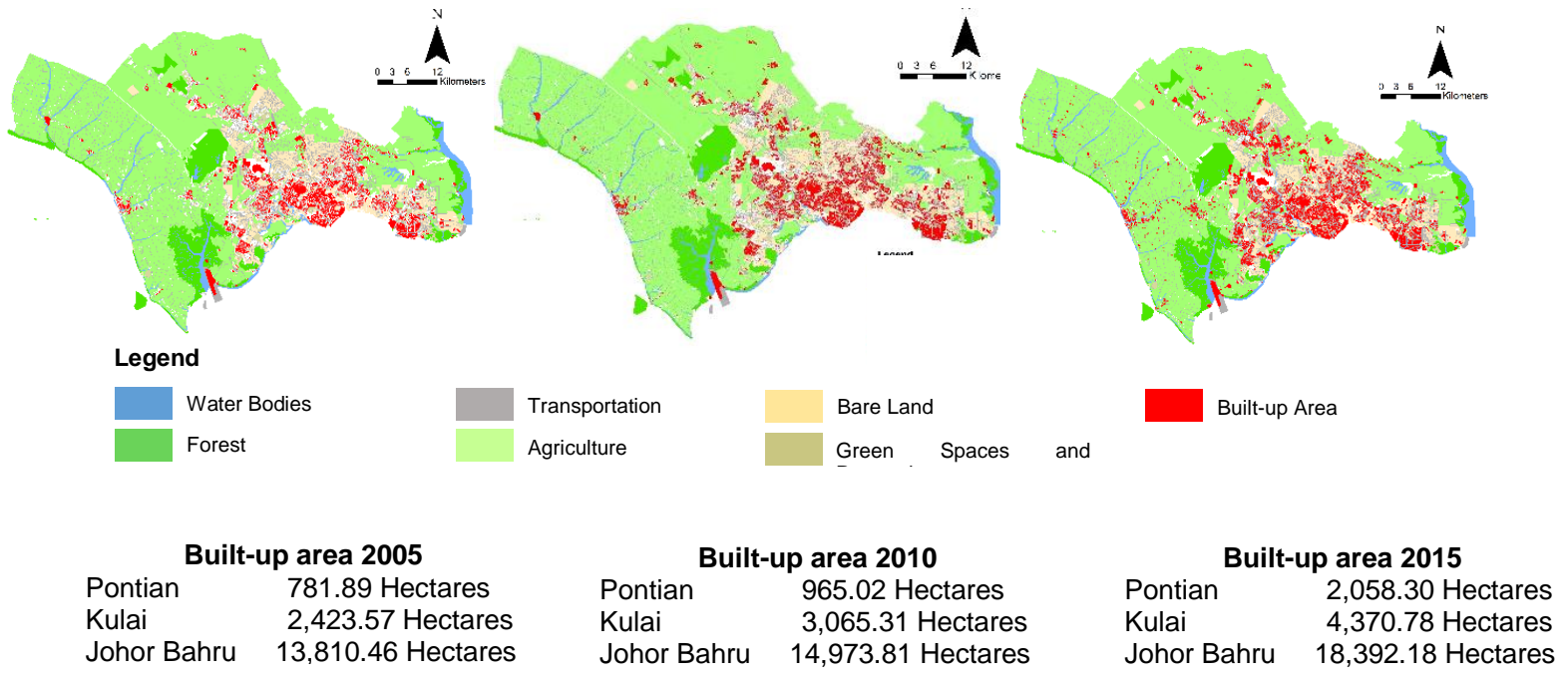

Figure 6 Land use/ land covers 2005, 2010, 2015 generated by using ArcGIS software

The result shows that from three districts within Iskandar Malaysia, namely Johor Bahru, Kulai and Pontian, the district of Pontian mostly affected of percentage of build-up areas. The result shows that there is an increase of $263.2 \%$ of the build-up area from the year 2005 to 2015 for the district of Pontian, $180.3 \%$ increased for the district of Kulai, and 133.2\% increased for the district of Johor Bahru. 

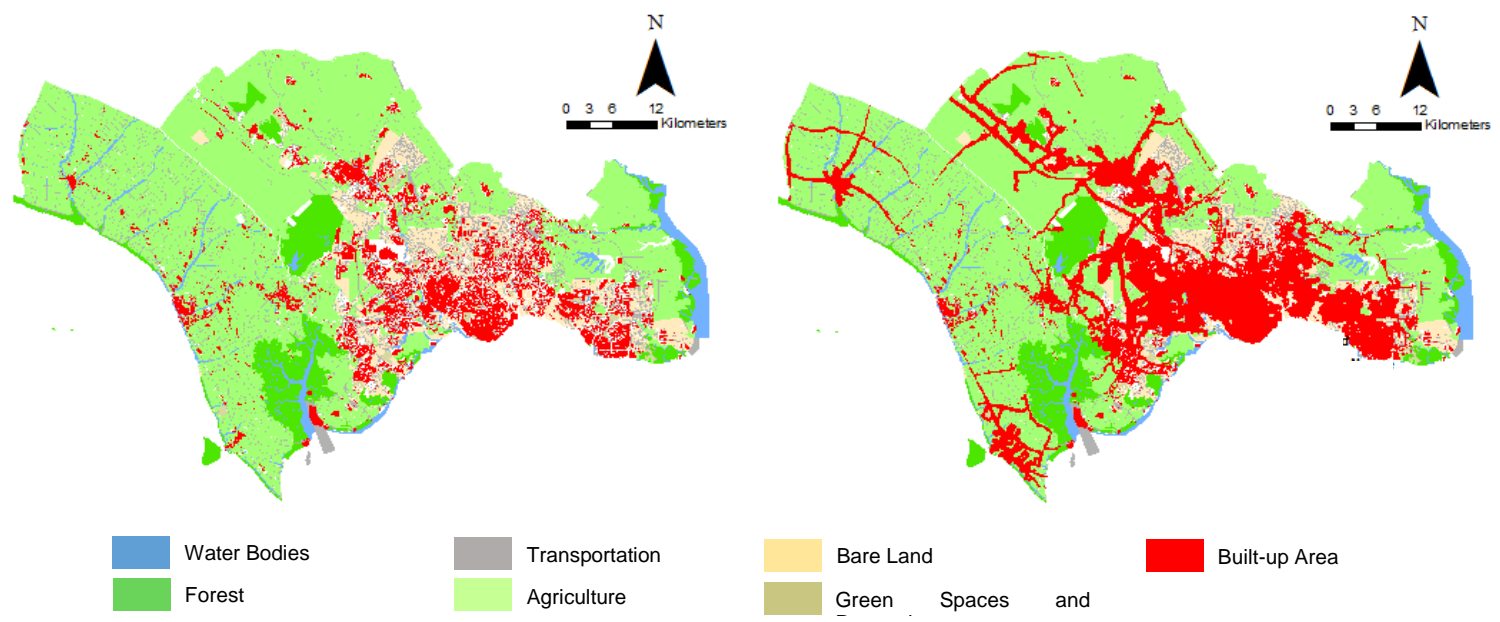

\begin{tabular}{lr}
\multicolumn{2}{c}{ Predicted build up area $\mathbf{2 0 3 0}$} \\
Pontian & $2,406.80$ Hectares \\
Kulai & $5,285.86$ Hectares \\
Johor Bahru & $20,748.76$ Hectares
\end{tabular}

Figure 7 Projection of Land use or land covers by the year 2030 and 2050 generated by using IDRISI software and MARKOV chain technique

Table 4 Detail Pontian district built-up area by Mukim for 2005, 2010, 2015 and projection of 2030 and 2050

\begin{tabular}{l|c|c|c|c|c}
\hline \multirow{2}{*}{ Mukim } & \multicolumn{5}{c}{ Area (Hectare) } \\
\cline { 2 - 6 } & $\mathbf{2 0 0 5}$ & $\mathbf{2 0 1 0}$ & $\mathbf{2 0 1 5}$ & $\mathbf{2 0 3 0}$ & $\mathbf{2 0 5 0}$ \\
\hline Api Api & 28.20 & 35.20 & 134.01 & 219.15 & 368.78 \\
\hline Ayer Baloi & 20.12 & 23.28 & 57.45 & 85.20 & 198.46 \\
\hline Ayer Masin & 15.82 & 20.26 & 55.28 & 88.64 & 295.13 \\
\hline Benut & 55.28 & 68.12 & 125.12 & 154.32 & 341.03 \\
\hline Jeram Batu & 165.63 & 250.82 & 492.77 & 520.97 & 3070.87 \\
\hline Pengkalan Raja & 11.16 & 11.16 & 21.15 & 37.16 & 238.51 \\
\hline Pontian & 258.63 & 310.00 & 620.17 & 630.52 & 2747.06 \\
\hline Rimba Terjun & 135.82 & 149.97 & 321.46 & 330.25 & 1032.71 \\
\hline Serkat & 42.10 & 45.90 & 116.77 & 214.77 & $1,420.23$ \\
\hline Sungai Karang & 18.54 & 18.54 & 26.54 & 33.95 & 81.68 \\
\hline Sungai Pinggan & 30.59 & 30.59 & 86.59 & 91.87 & 132.00 \\
\hline
\end{tabular}

Pontian District is prrojected to increase to 2,406.80 Hectares of build-up area by the year 2030 and 9,957.45 Hectares by 2050. The prediction is inconsistency with the data collected from Pontian Land Office which shows the application for land
Predicted build up area 2050

Pontian 9,957.45 Hectares

Kulai $\quad 16,558.94$ Hectares

Johor Bahru $\quad 40,001.43$ Hectares 


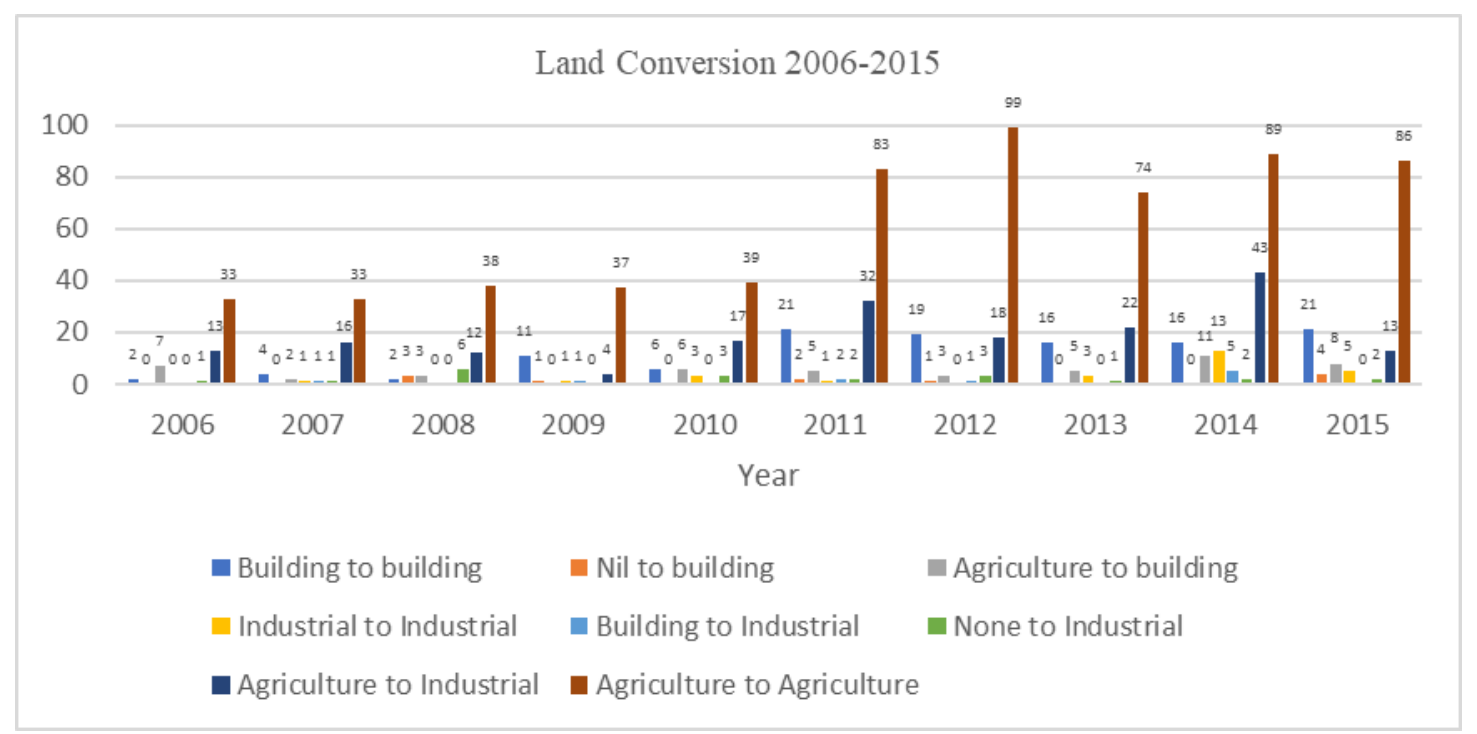

Figure 8 Land conversion 2006-2015.

(Source: Pontian land office)

Data obtained from Pontian District Council shows that there was a drastic increased in the numbers of applications of the planning permission after the announcement of the development of Iskandar Malaysia. For the year of 2001 to 2005, there are only 51 applications for Planning Permission were submitted, 144 applications between the year of 2006 to 2010, an increase of $282 \%$ and 319 applications for the year 2011 to 2015, an increase of $625 \%$ for the interval period of five years. The statistics suggest that the rapid and massive development of Iskandar Malaysia could give the early indication an impact on the pattern of land use and have altered the social, economic and environmental capital of community in Pontian. Due to the rapid economic growth and urban development of Pekan Nanas, its population is expected to increase rapidly by the year 2025 (MDP, 2016). Refer Figure 9.

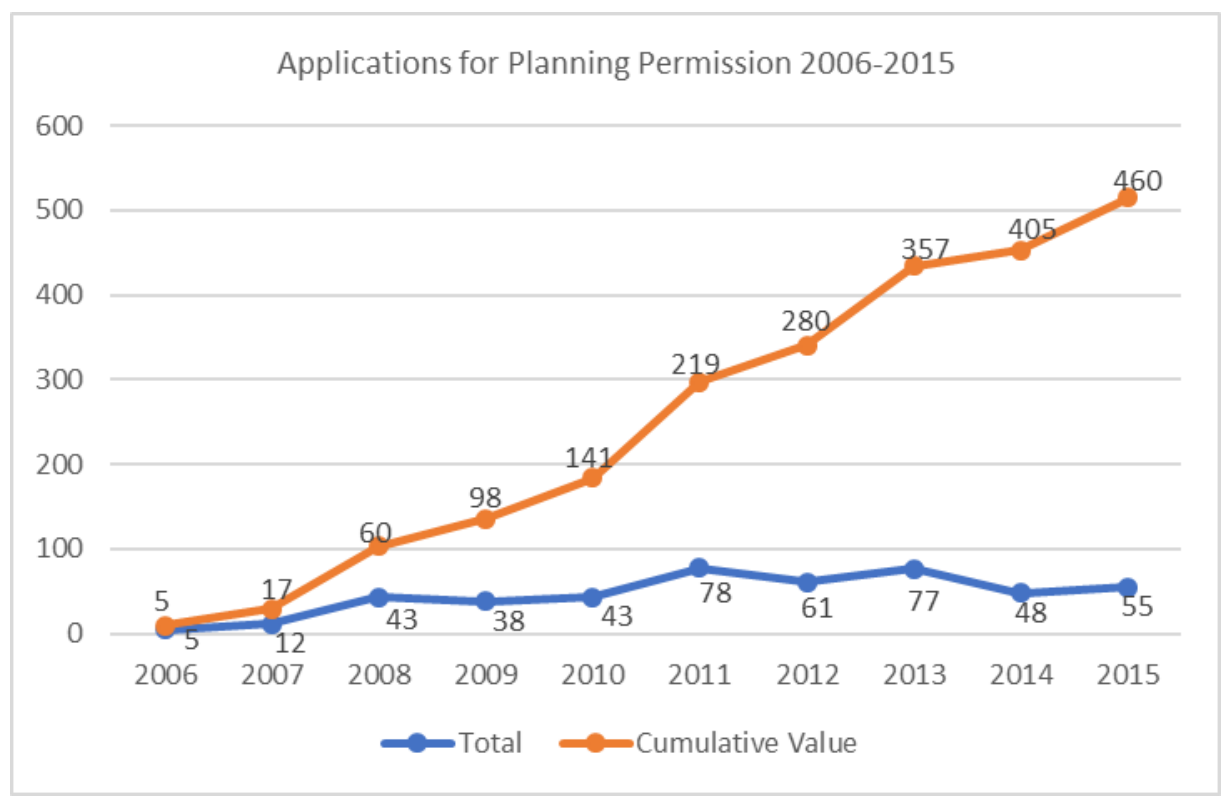

Figure 9 Applications for Planning Permission 2006-2015.

(Source: Pontian District Council) 


\subsection{Measuring resilience level of farmers in Pontian}

The survey questionnaire was formulated based on the list of indicators proposed in Table 5 and divided into three capitals. Economic capital with nine indicators, followed by social capital with 13 indicators and environmental capital with eight indicators which make up 30 questions in total. The questionguided survey which was conducted at four Kompleks Penghulu multipurpose hall. During the questionnaire guided survey, each respondent was asked to give a score of 1 to 10.1 for not agree, and 10 if they agree with the statement ask. The response from 72 farmers as shown in Table 5.

Table 5 Economic, Social and Environmental resilience mean score

\begin{tabular}{|c|c|c|c|c|c|c|c|c|c|}
\hline & \multicolumn{3}{|c|}{$\begin{array}{l}\text { ECONOMIC } \\
\qquad(\mathrm{N}=72)\end{array}$} & \multicolumn{3}{|c|}{$\begin{array}{c}\text { SOCIAL } \\
(\mathrm{N}=72)\end{array}$} & \multicolumn{3}{|c|}{$\begin{array}{c}\text { ENVIRONMENT } \\
(\mathrm{N}=72)\end{array}$} \\
\hline & & Mean & $\begin{array}{c}\text { Std. } \\
\text { Deviation }\end{array}$ & & Mean & $\begin{array}{c}\text { Std. } \\
\text { Deviation }\end{array}$ & & Mean & $\begin{array}{c}\text { Std. } \\
\text { Deviation }\end{array}$ \\
\hline & Q1 & 8.31 & 1.851 & Q10 & 8.31 & 2.107 & Q23 & 6.29 & 2.619 \\
\hline & Q2 & 7.61 & 2.205 & Q11 & 8.21 & 1.711 & Q24 & 6.11 & 2.587 \\
\hline & Q3 & 4.15 & 3.116 & Q12 & 8.82 & 1.202 & Q25 & 7.58 & 2.174 \\
\hline & $\mathrm{Q} 4$ & 5.13 & 3.184 & Q13 & 8.65 & 1.235 & Q26 & 7.51 & 2.883 \\
\hline & Q5 & 8.79 & 1.363 & Q14 & 6.64 & 1.916 & Q27 & 5.50 & 3.009 \\
\hline & Q6 & 6.79 & 2.264 & Q15 & 7.25 & 1.829 & Q28 & 6.10 & 2.913 \\
\hline & Q7 & 6.21 & 2.420 & Q16 & 6.69 & 2.243 & Q29 & 5.36 & 2.692 \\
\hline & Q8 & 6.92 & 1.813 & Q17 & 6.85 & 1.836 & Q30 & 7.31 & 1.881 \\
\hline & Q9 & 6.96 & 1.772 & Q18 & 6.88 & 1.776 & & & \\
\hline & & & & Q19 & 6.69 & 2.430 & & & \\
\hline & & & & Q20 & 6.06 & 2.572 & & & \\
\hline & & & & Q21 & 7.24 & 1.842 & & & \\
\hline & & & & Q22 & 4.15 & 2.532 & & & \\
\hline & \multicolumn{9}{|c|}{ Economic capital, Social capital and Environmental capital resilience score } \\
\hline Mean & \multicolumn{3}{|c|}{6.7623} & \multicolumn{3}{|c|}{7.1100} & \multicolumn{3}{|c|}{6.4705} \\
\hline $\begin{array}{l}\text { Std. } \\
\text { Deviation }\end{array}$ & \multicolumn{3}{|c|}{1.05497} & \multicolumn{3}{|c|}{1.00518} & \multicolumn{3}{|c|}{.82396} \\
\hline
\end{tabular}

\subsubsection{Economic capital}

Nine questions are representing nine indicators tested in this category, and the results from the data analysis presented in Table 5. The result illustrated in Table 5 indicate that majority of farmers agreed that their income had increased and stable compared to the last ten years with a mean score of 8.31 and 7.61 respectively. However, they also still need for the household to develop other sources of income and monetary help from other family member. They believe that the development in Iskandar Malaysia increased the demand for their agricultural production, and they satisfied with the help from government agencies in giving financial aids, funds and subsidies to farmer communities. They were also positive about the prospects in new forms of economic activities (agro tourismrelated initiatives) initiated by local leaders and government agencies with the involvement of local communities.

\subsubsection{Social capital}

Thirteen questions representing thirteen indicators in this category. The result shows that almost all indicators presented here indicated a high level of the social capital score, hence indicated a strong community social capital except for Q22. Majority of them believed that the development of Iskandar Malaysia does increase the related social problem to the local community. The social bonding among the farmer community is at the highest score (refer Q10-Q13) where a majority of them feel happy, have trust in each other and proud to be part of the community and intend to live and continue to stay with the community. The majority of the respondents have received training in relevant skills provided by government agencies such as the bee farming course, food packaging, tourist guiding and sewing (especially for female villagers). The lack of follow-up or monitoring overshadows the positive attitude towards such training after the training by related government agencies. The follow-up process by related agencies is required to assess which skills and new knowledge is given to the farmers has empowered and improved their socioeconomic standings. They also positive together with the young people not only pass down their knowledge but also get to know new knowledge and to be able to get involved in developing new opportunities and project in the community.

\subsubsection{Environmental capital}

Eight questions are representing eight indicators in this category. Based on the data analysis, the communities' environmental capital can be classified as weak compared with the other two capitals (economic and social). However, the mean score indicates that it is still satisfactory. The farmers acknowledged the efforts made by the government in providing necessary 
infrastructures such as roads, electricity, access to clean water and other related necessity (refer to Q25,26 and Q30). With continuous commitment from the government, the farmer communities were able to withstand the possibility of occurring natural disasters such as floods, landslide, soil erosion and casualties.
The finding from data analysis presented at Table 5 are then compared to the concept of community resilience as presented in Figure 5, and the resilience level of farmer communities in Pontian. As shown in Figure 10, all have well balance developed capitals which were indicated with the resilience score for economic capital at 6.76 , followed by social capital at 7.11 and environmental capital at 6.47 .

\section{Farmers}

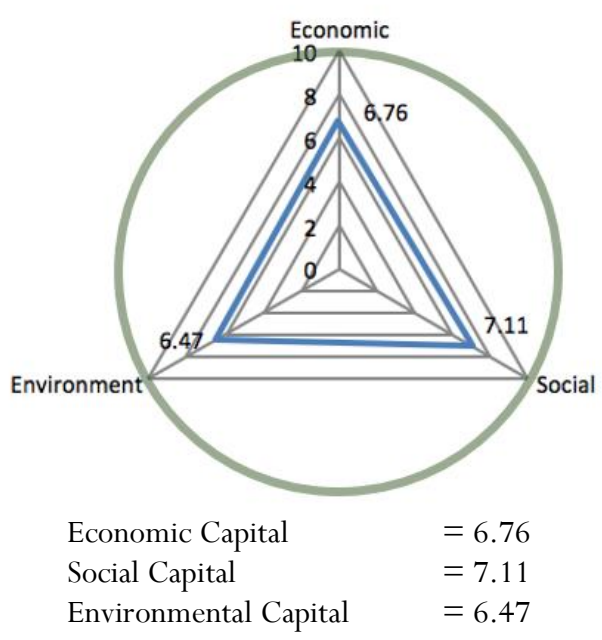

Figure 10 Community resilience level presented by economic, social and Environmental capital.

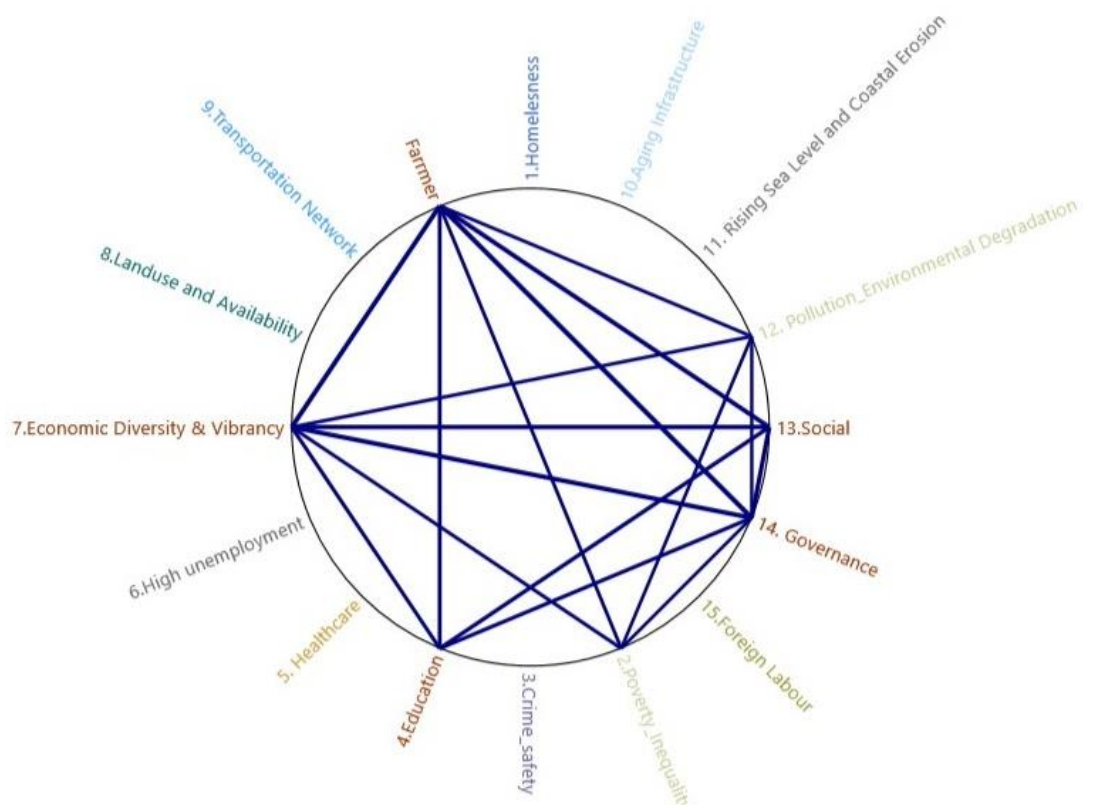

Figure 11 Nodes clustered by words similarity. 


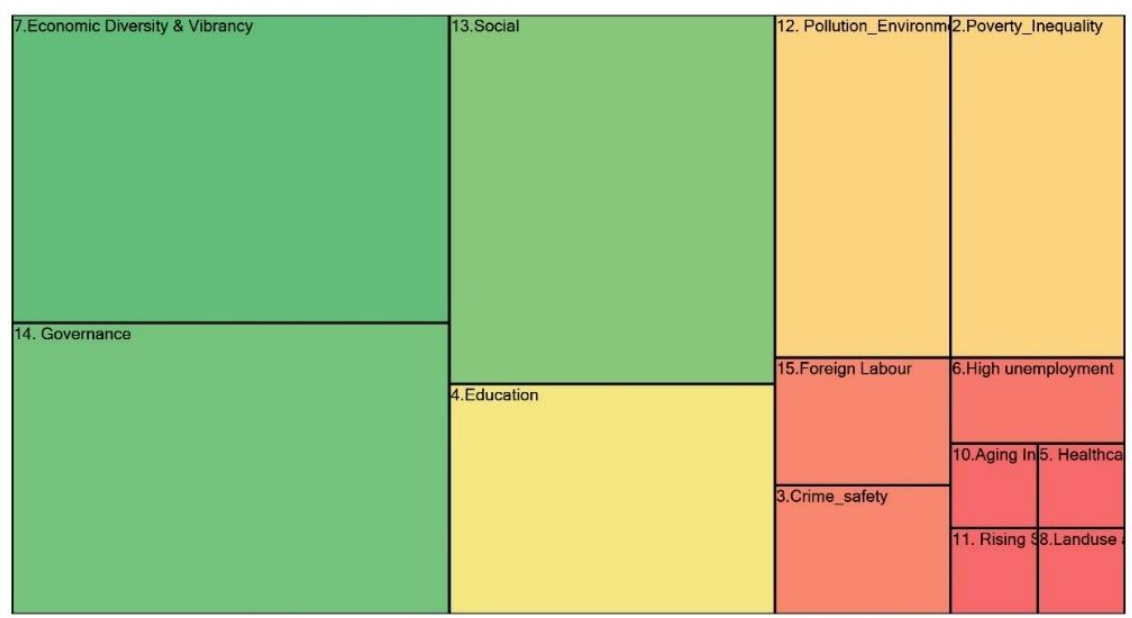

Figure 12 Hierarchy chart, Nodes compared by the number of coding references

The interview was formulated based on the three questions proposed in Table 5 to identify what are the factors that worry them economically, socially and environmentally. The respond from 25 farmers as shown in Figure 11 and Figure 12. The result shows that; six main factors can contribute to the ability of the farmers to adapt to the development of Iskandar Malaysia. There are economic diversity and vibrancy, governance, social, education, pollution \& environmental degradation and poverty and inequality. Governance and social factor are the additional two factor that had been discovered during the interview. The first factor is economic diversity and vibrancy. We might think that the Farmers may find themselves difficult to adapt to the economic development of Iskandar Malaysia due to their profession as a farmer without broad diversity and vibrancy as farmer is labour intense job. The development of Iskandar Malaysia undeniably creates a massive demand for product from farming activities, and the farmers took the initiative to change the farming as shown in Figure 10. The decisive score as shown in result questionnaires, question no 19 and 20 (refer Table 4) shows that the transfer of knowledge and skill from the older to the younger generation and new knowledge from younger generation shared to older generation.

The second most significant factor is governance. The government involvement in agricultural activities through their agricultural-related department in the form of government aid such as subsidies is vital as government may not put the priority on agricultural industry as the main economic activities in the development of Iskandar Malaysia. The third factor is social. Farmers may need stronger community bonding with the residents and the local leader. The social problem involving the communities, especially the younger generation, will jeopardize the future of the agricultural industry. The fourth factor is education. Farmers may need education in getting update with new technology in improving the productivity of their crops. The fifth most significant factor for the farmer is pollution and environmental degradation. They also suffer much from the development as many of the natural resources need to restructure to adapt the economic activities such as lands are acquired to build infrastructure where the kampung lifestyle as a farmer may be destroyed. The sixth factor is about poverty and inequality. Due to the way how Iskandar Malaysia developed, farmers have in mind that farming activities may not be the main priority in developing Iskandar Malaysia.

From the quantitative analysis, there are exciting findings that relate to farmers, specifically in Pontian. The finding is slightly at variance with the research hypothesis which made them difference from other developed nations, whereas many critical rural kinds of literature has highlighted. (Marsden, Milbourne, Kitchen, \& Bishop, 2003); (Robinson, 2008) Highlighted that many farming communities are relatively conservative in the way they address the need for change and innovation where farmers tend to stick to what they know best about how their parents and grandparents farmed and to how things have always done (Wilson G. A., 2007); (Burton, Kuczera, \& Schwarz, 2008). These findings are related to respondents and farming communities' own experiences with their past. The ability to adapt to a different type of government farming program is the factor that enhance adaptability. The development of Iskandar Malaysia undeniably creates a massive demand for product from farming activities. The improvement level of education among the farmers and family members has improved. They can manage the farm by using new technology but also give an extra advantage and opportunity for them to find a job close to their community and helps improve economic capital at the community level by reducing dependency on farming activities. Malaysian has experienced tremendous economic growth since its independence in 1957. The current economic development in the country has transformed Malaysia from an agricultural nation to an industrial country and is moving well along the path of modern economic (Subramaniam, 2008). As a result, the agricultural sector share in a total gross domestic product (GDP) and the share of employment in the sector have declined steadily (refer to Figure 13). 


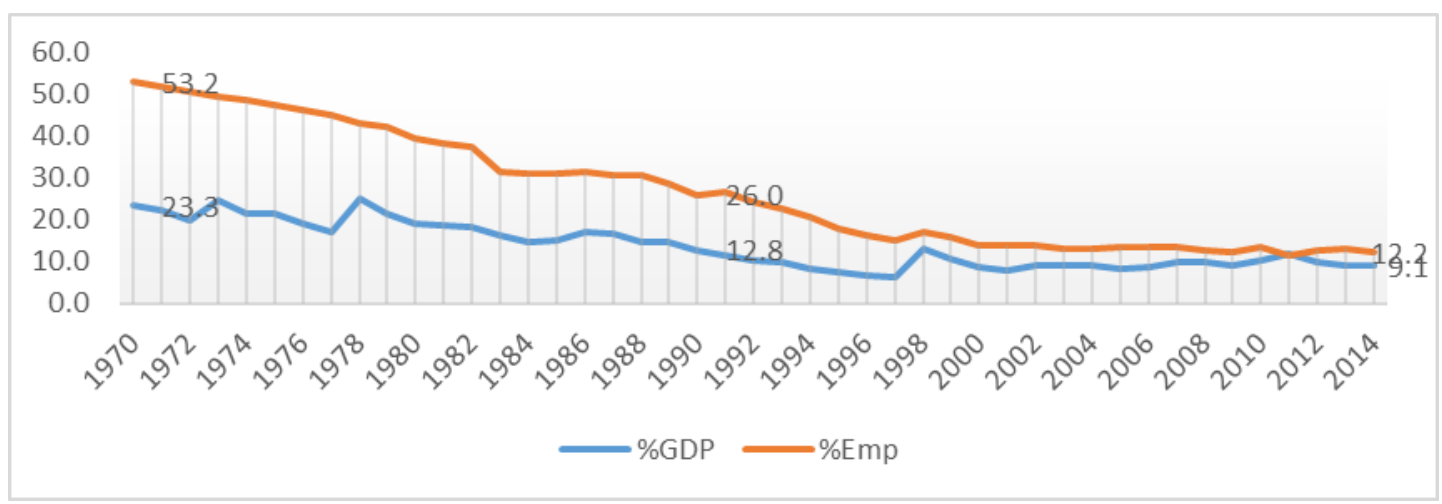

Figure 13 The contribution of agricultural (GDP) and share of employment Source: Department of Statistic, Labour Force Survey 2014

At the national level the share of employment in agriculture has declined from 53.5\% which contribute $23.5 \%$ of Gross Domestic Product (GDP) in 1970 to $12.2 \%$ share of employment which contributes $9.1 \%$ GDP in 2014 due to economic structural changes. The contribution of Agricultural to employment tends to decrease by 1.3 per cent every year while the contribution of agriculture to GDP tends to decrease 0.6 by per cent every year.

At the state level, $8.6 \%$ of Johor population involve in the agricultural sector in the year 2016. Rapid development and industrialization have taken more agricultural land spaces to a housing project or industrial site. The built-up area for the district of Pontian experiencing the most increased in terms of percentage compared with the other two districts within Wilayah Iskandar, district of Kulai and district of Johor Bahru. Based on the result, the farmer communities in Pontian tend to have the ability to adapt to the rapid development at Iskandar Malaysia. Data collected from the Johor Agricultural department under Ministry of agriculture, tend to agree that the farmer communities in Pontian can adapt and able to change to different types of farming activities to suit the land-use change and current market demand. It is because most of the farmer is the owner of their farmland and the majority of them own smallholders ( 2 hectares -5 hectares) considerably, which make them easy to change to another economically sound crop. Historically, the primary agricultural product of Pontian in early 1960s was dominated by industrial crop, followed by rubber tree, pineapple, cocoa in 1970s, then the domination of palm oil in early 1980s until now. The data presented in Table 6 shows that from 2006 to 2016 there is a significant drop of fruit crop which was reduced to 52.36 per cent followed by industrial crop minus 44.5 per cent, rubber tree minus 48.99 per cent. The combination of the drop in market price and the need of intensive labor force with the minimum return might be the cause. The data also have shown that the herbs, cash crop and vegetable increased more than 100 per cent. Apart from the demand created by the new market in Iskandar Malaysia; this particular crop requires a small space of land to manage, quickly returned of investment and suite to the young farmers in the community.

Table 6 Pontian crop statistics (2006-2016). Source: Johor Agricultural Department (2006-2016)

\begin{tabular}{c|c|c|c|c|c|c|c|c}
\hline Year & Industrial Crops & Spices & Herbs & Cash Crops & Vegetables & Fruit Crops & Rubber Tree & Palm Oil \\
\hline 2006 & 7135.06 & 37.27 & 28.00 & 530.57 & 91.14 & 10164.90 & 7151.00 & 43377.29 \\
\hline 2008 & 6154.00 & 38.00 & 31.00 & 539.00 & 96.00 & 8787.00 & 5935.00 & 45474.00 \\
\hline 2010 & N/A & N/A & N/A & N/A & N/A & N/A & N/A & N/A \\
\hline 2012 & 5313.80 & 8.20 & 1.00 & 891.00 & 107.83 & 6952.86 & 3648.00 & 42889.00 \\
\hline 2014 & 4058.10 & 40.50 & 4.00 & 912.80 & 94.00 & 4979.10 & N/A & N/A \\
\hline 2016 & 3960.10 & 33.00 & 86.40 & 1185.80 & 210.52 & 4842.50 & N/A & N/A \\
\hline $\begin{array}{c}\text { Percentage } \\
(\%)\end{array}$ & -44.50 & -11.46 & 208.57 & 123.50 & 130.99 & -52.36 & -48.99 & -1.13 \\
\hline
\end{tabular}

\section{Conclusions}

This study's primary contribution lies in the ability to illuminate how the farmer communities in Pontian district can withstand or adapt from a threat to social, economy and environment. Taking into account the massive development in Iskandar Malaysia for the past thirteen years, scholars and professionals from various disciplines have begun to address issues of community resilience. This study contributes to a deep and detailed understanding that the rapid and massive development of Iskandar Malaysia not only indicates an impact on the pattern of land use, it is also altered its social, economic and environmental capitals of farmers in Pontian district. Moreover, setting Pontian district in relation to Iskandar Malaysia as the object of this study also expand the theory of resilience thinking study as an addition to the concept 
of sustainable development in planning a new development in the future.

The findings revealed the perspective of individuals, community, and system resilience capacity to survive. It was found that farmers were able to adapt to various stresses. The result indicates that individuals and communities can be adaptive, absorptive, and transformative. With this knowledge, the triple threat of urbanization, globalization and climate change can be better prepared for its current and future impact. The notion of resilience thinking in its study illustrate a systematic perspective of those particular challenges and how it impacts the farmers. With knowledge, it will prepare them to think differently and comprehensively for possible solutions that are needed to face future challenges.

The most critical aspect for the community is to understand the importance of ethical values. The value proposition of resilience thinking its use for good economic, social and environmental practices as found in Pontian farmers impacted by Iskandar Malaysia. Participatory among members of the community is vital to ensure that there is good development practice while giving space for voices of stakeholders are to be heard. When we think about the additional value of what resilience brings, it helps us to educate stakeholders, particularly farmers, with proper knowledge for a better understanding. With that, we gain insight into the core of the problem. What may seem to be a problem initially might not be a problem. Redefining the problem at stake allows us to access not only a particular sector or issue but how it relates to other issues and challenges. From there, we can look across scale, across time, understanding and mapping of and various stakeholders through how they interact with one another and the connection with one another is a critical aspect of resilience thinking. The challengers to the parties involved in development are how we begin to apply this practice and implementing resilience in the development system. Most of the previous is more about learning and influencing insight but not about implementing what we have learned from building a community resilient.

\section{References}

Authority, I. R. (2006). Comprehensive Development Plan i. Iskandar Malaysia, Malaysia: Khazanah Nasional.

Authority, I. R. (2014). Comprehensive Development Plan ii. Iskandar Malaysia: Malaysia: Khazanah Nasional.

Burton, R. J., Kuczera, C., \& Schwarz, G. (2008). Exploring Farmers' Cultural Resistance to Voluntary Agri-environmental Schemes. Sociologia Ruralist.

Butt, Amna, Rabia, Shabbir, Ahmad, S. S., \& Aziz, N. (2015). 'Land Use Change Maooing and Analysis Using Remote Sensing and GIS. A Case of simly Watershed, Islamabad, Pakistan'. The Egyptian Journal of Remote Sensing And Space Science, 18(2): 251-259. Retrieved from http://dx.doi.org/10.1016/j.ejrs.2015.07.003

Chaskin, R. (2008). 'Resilience, community, and resilient communities: conditioning contexts and collective action'. Child Care in Practice, 14: 65-74.
Cutter, S., Barnes, L., Berry, M., Burton, C., Evans, E., Tate, E., \& Webb, J. (2008). 'A place-based model for understanding community resilience to natural disaster'. Global Environmental Change, 18: 598-606.

Ekins, P., Simon, S., Deutsch, L., Folke, C., \& De Groot, R. (2003). 'A framework for the practical application of the concepts of critical natural capital and strong sustainability'. Ecological Economics, 44: 165185.

Folke, C. (2006). Resilience: the emergence of a perspective for socialecological system analyses. Global Environmental Change, 16(3): 253267.

Forbes, B., Stammler, F., Kumpula, T., Meschtyb, N., Pajunen, A., \& Kaarlejarvi, E. (2009). 'High resilience in hte Yamal-Nenets socialecological system, West Siberian Arctic. Russia'. Proceedings of the National Academy of Science of the USA, 106: 22041-22048.

Gahin, R., Veleva, V., \& Hart, M. (2003). 'Do indicators help create sustainable communities?' Local Environment, 8: 661-666. doi:10.1080/1354983032000152752

Gordon, M. (2014). Rockfeller Foundation 100 Resilient Cities. National Lifelines Forum.

Jaiswal, Kumar, R., \& Mukherjee, R. S. (1999). 'Application of Remote Sensing Technology for Land Use/ Land Cover Change Analysis'. Journal of the Indian Society of Remote Sensing, 27(2): 123. Retrieved from https://doi.org/10.1007/BE02990808

Kamarudin, K., Ngah, I., Razak, K., Ibrahim, M., \& Harun, A. (2014). Resilience in a community: the story of Orang Asli of Royal BelumTemengor Forest Complex. Proceding of The 5th International Conference and Field Study in Malaysia, 168-183. Perak, Malaysia.

Lebel, L., Anderies, J. M., Campbell, B., Folke, C., Hatfield-Dodds, S., Hughes, T. P., \& Wilson, J. (2006). Governance and the Capacity to Manage Resilience in Regional Social-Ecological Systems. Ecology and Society, 11(1): 19 .

LEDDRA, L. a. (2011). 'Theory of responses to land and ecosystem degradation and desertification in croplands/grazing lands/forests. Brussels: European Commission

Magis, K. (2010). 'Community resilience: an indicator of social sustainability'. Society and Natural Resources, 23: 401-416.

Marsden, T., Milbourne, P., Kitchen, L., \& Bishop, K. (2003). Communities in Nature: The Constructive and Undersanding of Forest Natures. Sociologia Ruralist.

MDP, M. D. (2016). Pontian District Local Plan 2015-2025. Pontian, Johor, Malaysia.

Mengistu, Daniel, \& Salami, D. A. (2008). Application of Remote Sensing and GIS in Land Use/ Land Cover Mapping and Change Detection in a Part of South Western Nigeria. African Journal of Environmental Science and Technology. 1:5.

Misra, Ankita, R, M. M., \& Vethamony, P. (2015). Assessment of the Land Use/land Cover (LU/LC) and Mangrove Changes along the Mandovi-Zuari Estuarine Complex of Goa, India. Arabian Journal of Geoscience, 8(1): 267-279. Retrieved from https: / /doi.org/10.1007/s12517-013-1220-y 
Islam, G. M. N., Yew, T. S., Abdullah, N. M. R., \& Viswanathan, K. K. (2011). Social capital, community based management, and fishers' livelihood in Bangladesh. Ocean and Coastal Management, 54(2): 173180. doi:10.1016/j.ocecoaman.2010.10.026

Ostrom, E. (2009). 'A general framework for analuzing sustainability of social-ecological system'. Science, 325: 419-422.

van Oudenhoven, F., Mijatovic, D., \& Eyzaguirre, P. (2011). Socialecological indicators of resilience in agrarian and natural landscapes. Management of Environmental Quality: An International Journal, 22: 154-173. doi:10.1108/14777831111113356

Parnwell, M. J. G. (2007). Neolocalism and Renascent Social Capital in Northeast Thailand. Environment and Planning D: Society and Space, 25(6): 990-1014. doi: $10.1068 / \mathrm{d} 451 \mathrm{t}$

Rizk, Ibrahim, Mosbeh, \& Rashed. (2015). Monitoring Urban Growth and Land Use Change Detection with GIS and Remote Sensing Techniques in Daqahlia Governorate Egypt. Internationl Journal of Sustainable Built Environment, 4(1): 117-24. Retrieved from http://dx.doi.org/10.1016/j.ijsbe.2015.02.005

Robinson, G. M. (2008). Sustainable Rural System: Sustainable Agriculture and Rural Communities. Great Britain: Ashgate Publishing Limited.
Smit, B., \& Wandel, J. (2006). Adaptation, adaptive capacity and vulnerability. Global Environmental Change, 16(3): 282-292. doi:https://doi.org/10.1016/j.gloenvcha.2006.03.008

Thomalla, F., \& Klocker Larsen, R. (2010). 'Resilience in the context of tsunami early warning systems and community disaster preparedness in the Indian Ocean Region'. Environmental Hazards, 9: 249-265.

Western, J., Stimson, R., Baum, S., \& Van Gellecum, Y. (2005). Measuring community strength and social capital. Regional Studies, 39: 1095-1109.

Wilson, G. (2010). Multifunctional 'quality' and rural community resilience. Transactions of the institute of British Geographers, 35: 364-381.

Wilson, G. (2012). Community Resilience and Environmental Transition. United Kingdom: CRC Press

Wilson, G. A. (2007). Multifunctional Agriculture: A Transition Theory Perspective. United Kingdom: CAB International.

Yagoub, M., \& Giridhar, R. K. (2006). Monitoring Coastal Zone Land Use and Land Cover Changes of Abu Dhabi Using Remote Sensing. Journal of the Indian Society of Remote Sensing, 34(1): 57-68. 